\title{
DESAIN DAN IMPLEMENTASI MEKANISME TANDA TANGAN DIJITAL DALAM PERTUKARAN DATA DENGAN HASH MD5 DAN ENKRIPSI/DEKRIPSI MENGGUNAKAN ALGORITMA RSA
}

\author{
Junaidy B. Sanger \\ Program Studi Teknik Informatika \\ Universitas Katolik De La Salle Manado \\ e-mail: junsanger@gmail.com
}

\begin{abstract}
Information exchange in a network could lead into some problems, such as privacy problem, authentication problem, data integrity problem, and non repudiation problem. Thus, precise security acts are needed to solve those problems. Digital signature is a solution to solve those problems. Digital signature is basically just like a written signature, which is used to authenticate documents. The difference is that the written signature usually describes the name of a signer whereas the digital signature consists of cryptography codes of a message and a sender. Digital signature using hash function is one of the most used digital signatures. Unfortunately, this kind of digital signature can not solve all given problems, such as privacy problem and non repudiation problem. Therefore, RSA algorithm is needed to solve that problem. The result of this research is the implementation of digital signature along with RSA algorithm and MD5 hash function in a data transfer application.
\end{abstract}

Keywords: $\quad$ Digital Signature, MD5 Hash Function, RSA Algorithm

\section{A. PENDAHULUAN}

Perkembangan teknologi dewasa ini sangat membantu perkembangan kehidupan manusia di segala aspek kehidupan, termasuk salah satunya bidang komunikasi. Sehingga manusia bisa dengan mudah untuk saling bertukar informasi satu sama lain. Teknologi internet merupakan salah satu bukti konkret yang membantu manusia untuk dapat saling bertukar informasi dengan mudah, murah dan cepat. Pertukaran informasi tersebut dapat dilakukan lewat $e$ mail (electronic mail) atau dengan menggunakan fasilitas chatting. Ini sangatlah berbeda jika pengiriman pesan dengan menggunakan cara konvensional yaitu dikirim lewat pos. Selain biaya yang harus dikeluarkan relatif lebih mahal, waktu yang diperlukan juga cukup lama agar pesan yang dikirim bisa dibaca oleh orang yang dimaksud.
Namun pertukaran informasi lewat sebuah jaringan, seperti internet, dapat membawa masalah bagi penyebaran pesan yang hendak dikirim. Masalah-masalah yang ada antara lain adalah pesan yang dikirim dapat dibaca oleh orang yang tidak berkepentingan (masalah kerahasiaan) sehingga dapat merugikan pengirim pesan. Masalah berikutnya adalah apakah benarbenar pesan yang dikirim tersebut berasal dari pengirim yang benar? (masalah keaslian/otentikasi). Masalah selanjutnya adalah pesan yang diterima telah dimodifikasi dalam perjalanan oleh pihak lain (masalah keutuhan). Masalah terakhir adalah si pengirim menyangkal kalau pesan yang dikirim berasal dari dirinya (non repudiation). Oleh karena itu, perlu dilakukan tindakan pengamanan yang tepat untuk mengatasi masalah-masalah tersebut. 
Tanda tangan dijital atau yang lebih dikenal dengan digital signature merupakan salah satu solusi untuk mengatasi masalahmasalah di atas. Tanda tangan dijital memiliki fungsi sama seperti dengan tanda tangan pada dokumen biasa, yaitu untuk mengabsahkan dokumen. Perbedaannya yaitu pada bentuknya, tanda tangan biasa berupa goresan simbol yang unik sedangkan tanda tangan dijital berupa kode-kode yang berisi nilai kriptografis dimana kode-kode tersebut bergantung pada pesan dan pengirim pesan.

Salah satu tanda tangan dijital yang banyak digunakan adalah tanda tangan dijital dengan fungsi hash (hash function). Fungsi hash yang digunakan adalah fungsi hash MD5. MD5 atau Message Digest 5 adalah fungsi hash satu arah untuk mendapatkan nilai hash sepanjang 128 bit dari pesan yang ukurannya sembarang. Sayangnya, tanda tangan dijital dengan fungsi hash tersebut tidak dapat menjawab semua masalah yang ada seperti masalah kerahasiaan dan non repudiation. Oleh karena itu, algoritma RSA dibutuhkan untuk bisa mengatasi masalah tersebut.

RSA adalah algoritma kriptografi kunci-publik yang keamanannya terletak pada sulitnya menfaktorkan bilangan yang besar menjadi faktor-faktor prima. Tujuan dari penelitian ini adalah untuk membangun suatu alternatif aplikasi untuk pertukaran informasi dengan mengimplementasikan fungsi hash MD5 dan algoritma RSA.

\section{B. TINJAUAN PUSTAKA}

\section{Kriptografi}

Cryptography (Kriptografi) berasal dari Bahasa Yunani, yaitu: "Cryptos" berarti "Secret" (Rahasia) dan "Graphein" berarti "Writing" (Tulisan). Jadi, secara etimologis Cryptography berarti "Secret Writing" atau Tulisan Rahasia (Munir 2006).
Enkripsi adalah sebuah proses yang melakukan perubahan sebuah kode dari yang bisa dimengerti (plaintext) menjadi sebuah kode yang tidak bisa dimengerti (ciphertext). Sedangkan proses kebalikannya untuk mengubah ciphertext menjadi plaintext disebut dekripsi.

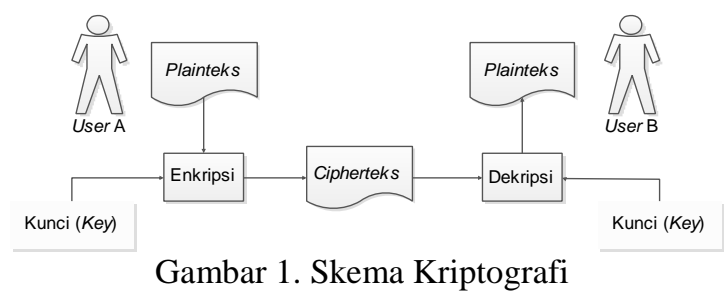

Secara umum operasi enkripsi dan dekripsi secara matematis dapat digambarkan sebagai berikut:

$$
\begin{aligned}
& \mathrm{EK}(\mathrm{M})=\mathrm{C} \text { \{proses enkripsi } \\
& \mathrm{DK}(\mathrm{C})=\mathrm{M} \text { \{proses dekripsi }
\end{aligned}
$$

Pada proses enkripsi pesan $\mathrm{M}$ dengan suatu kunci K disandikan menjadi pesan C. Pada proses dekripsi pesan $\mathrm{C}$ dengan kunci $\mathrm{K}$ disandikan menjadi pesan semula yaitu M. Misalnya S (sender) mengirim sebuah pesan ke $\mathrm{R}$ (receiver) dengan media transmisi T. Diluar, ada $\mathrm{O}$ yang menginginkan pesan tersebut dan mencoba untuk mengakses secara ilegal pesan tersebut. O disebut interceptor. Setelah $\mathrm{S}$ mengirim pesan ke $\mathrm{R}$ melalui media $\mathrm{T}, \mathrm{O}$ bisa mengakses pesan tersebut dengan caracara sebagai berikut:

a. Menganggu pesan, dengan mencegah pesan sampai ke $\mathrm{R}$.

b. Mencegat pesan, dengan cara mengetahui isi pesan tersebut.

c. Mengubah pesan dari bentuk aslinya dengan cara apapun.

d. Memalsukan pesan dan mengirimkan pesan tersebut seolah-olah dikirim oleh S.

Untuk melindungi pesan asli dari gangguan seperti ini dan menjamin keamanan dan kerahasiaan data maka mulai dikenal sistem kriptografi untuk melindungi data, yaitu dengan mengenkripsi pesan dan 
untuk bisa membaca pesan kembali seperti aslinya pesan harus didekripsi. Kriptografi merupakan cara yang paling praktis untuk melindungi data yang ditransmisikan melalui sarana telekomunikasi (Juliasari 2002).

Ada juga definisi lain tentang kriptografi, yaitu ilmu yang mempelajari teknik-teknik matematika yang berhubungan dengan aspek keamanan informasi seperti kerahasiaan, integritas data serta otentikasi (Menezes 1996).

Seperti yang disebut dalam buku Handbook of Applied Cryptography by A. Menezes, P. van Oorchot, and S. Vanstone, kriptografi memiliki 4 tujuan utama, yaitu:

1. Kerahasiaan

(Confidentiality) merupakan sebuah layanan yang ditujukan untuk menjaga agar pesan tidak dapat dibaca oleh pihak-pihak yang tidak berhak.

2. Keutuhan Data (Data Integrity) merupakan sebuah layanan yang menjamin bahwa pesan masih asli/utuh atau belum pernah dimanipulasi selama pengiriman.

3. Otentikasi (Authentication) merupakan sebuah layanan yang berhubungan dengan identifikasi, baik mengidentifikasi kebenaran dari pihak-pihak yang berkomunikasi maupun mengidentifikasi kebenaran dari sumber pesan,

4. Nirpenyangkalan (Non-Repudiation) merupakan sebuah layanan bertujuan mencegah adanya pihak yang menyangkal tanggung jawab atau tindakan yang dilakukan.

\section{Tanda tangan dijital dalam Kriptografi}

Sejak berabad-abad lamanya, tanda tangan digunakan untuk membuktikan otentikasi dokumen kertas. Tanda tangan mempunyai karakteristik sebagai berikut (Schneiner 1996):

1. Tanda tangan adalah bukti yang otentik.
2. Tanda tangan tidak dapat dilupakan.

3. Tanda tangan tidak dapat dipindah untuk digunakan ulang.

4. Dokumen yang telah ditandatangani tidak dapat diubah.

5. Tanda tangan tidak dapat disangkal (repudiation).

Fungsi tanda tangan pada dokumen kertas juga diterapkan untuk otentikasi pada data dijital seperti pesan yang dikirim melalui saluran komunikasi dan dokumen elektronis yang disimpan di dalam memori komputer. Yang dimaksud dengan tanda tangan dijital bukanlah tanda tangan yang di-digitisasi dengan alat scanner, tetapi suatu nilai kriptografis yang bergantung pada pesan dan pengirim pesan (Hal ini kontras dengan tanda tangan pada dokumen kertas yang bergantung hanya pada pengirim dan selalu sama untuk semua dokumen).

Teknologi tanda tangan dijital memanfaatkan teknologi kunci publik. Sepasang kunci publik-privat dibuat untuk keperluan seseorang. Kunci privat disimpan oleh pemiliknya. Kunci privat juga digunakan untuk membuat tanda tangan dijital. Sedangkan kunci publik dapat diserahkan kepada siapa saja yang ingin memeriksa tanda tangan dijital yang bersangkutan pada suatu dokumen atau pesan yang diterimanya. Proses pembuatan dan pemeriksaan tanda tangan ini melibatkan sejumlah teknik kriptografi seperti hashing (membuat 'sidik jari' dokumen) dan enkripsi asimetris (Wibowo 1998). Teknologi kunci publik juga bisa digunakan untuk menyandikan atau merahasiakan isi dokumen.

Gambaran yang lebih baik tentang tanda tangan dijital adalah sebagai berikut (Youd 1996):

Bob memiliki 2 kunci, yaitu kunci publik dan kunci privat. Dalam pekerjaannya, Bob bekerja dengan 3 orang partner, yaitu Pat, Doug dan Susan. Kunci 
publik Bob dapat dimiliki oleh semua orang yang membutuhkan tetapi kunci privat Bob disimpan untuk dirinya sendiri.

Susan adalah salah satu partner kerja Bob, dapat mengenkripsi pesan dengan menggunakan kunci publik milik Bob dan dengan menggunakan kunci privatnya, Bob mendekripsi pesan yang dikirim Susan. Tidak ada satupun yang dapat mengakses dan mengerti pesan Susan yang terenkripsi. Karena tanpa kunci privat Bob, pesan tersebut tidak berarti apa-apa.

Dengan kunci privat dan perangkat lunak yang sesuai, Bob dapat meletakkan tanda tangan dijital dalam dokumen atau data-data lain. Tanda tangan dijital ini unik untuk Bob dan sulit dipalsukan.

Tanda tangan dijital memanfaatkan fungsi hash satu arah untuk menjamin tanda tangan itu hanya berlaku untuk dokumen yang bersangkutan. Tetapi bukan dokumen tersebut secara keseluruhan yang ditandatangani. Biasanya yang ditandatangani hanyalah sidik jari dari dokumen itu dengan menggunakan kunci privat.

Untuk menandatangani sebuah dokumen, perangkat lunak yang digunakan Bob akan membuat pesan diproses menjadi beberapa karakter, ini yang disebut hashing. Beberapa karakter ini disebut message digest. Tidak mungkin untuk mengubah sebuah message digest kembali ke bentuk data asalnya. Karakteristik yang dimiliki oleh message digest adalah sebagai berikut (Krutz et al. 2003):

1. Fungsi hash yang digunakan dalam pembuatan tanda tangan digital merupakan fungsi hash satu arah, artinya message digest yang telah dibuat tidak dapat dikembalikan ke bentuk asalnya.

2. Dua file yang berbeda tidak mungkin mempunyai message digest yang sama.

3. Jika diberikan sebuah file dan message digest yang sesuai, maka tidak mungkin untuk menemukan file lain dengan message digest yang sama.

4. Message digest seharusnya dibentuk dengan menggunakan semua data dari file aslinya.

Perangkat lunak yang digunakan Bob kemudian mengenkripsi message digest dengan menggunakan kunci privat Bob. Kemudian tanda tangan tersebut ditambahkan ke dokumen yang akan dikirim. Bob akan mengirimkan dokumen tersebut ke Pat. Pertama Pat mengirimkan kunci publiknya kepada Bob dan Bob mengirimkan kunci publiknya kepada Pat. Kunci publik dari Pat akan digunakan Bob untuk mengenkripsi dokumen yang akan dikirim. Hasil Enkripsi tersebut dikirim ke Pat. Pat kemudian menerima dokumen yang telah dienkripsi tersebut. Pat mendekripsi dokumen itu dengan kunci privatnya. Jika berhasil, perangkat lunak milik Pat selanjutnya meng-hash data dokumen tersebut menjadi sebuah message digest. Kemudian dengan menggunakan kunci publik milik Bob, Pat membandingkan message digest dari perangkat lunaknya dan message digest yang dikirim oleh Bob. Kunci publik Bob berguna untuk mendekripsi tanda tangan milik Bob.

Singkatnya, keabsahan tanda tangan dijital itu dapat diperiksa oleh Pat. Pertamatama Pat membuat lagi message digest dari pesan yang diterimanya. Lalu Pat mendekripsi tanda tangan dijital Bob untuk mendapatkan message digest yang asli. Pat kemudian membandingkan kedua sidik jari tersebut. Jika kedua sidik jari tersebut sama, dapat diyakini bahwa pesan tersebut benarbenar ditandatangani oleh Bob.

\section{Hash Function MD5}

Fungsi hash adalah fungsi yang menerima masukan string yang panjangnya sembarang dan mengkonversinya menjadi string keluaran (message digest) yang 
panjangnya tetap (fixed) dan biasanya dengan ukuran yang jauh lebih kecil dari ukuran string semula. Satu arah berarti tidak mempunyai fungsi untuk melakukan pengembalian nilai yang sudah di enkripsi.

MD5 (Message Digest 5) adalah fungsi hash satu-arah yang dibuat oleh Ronald Rivest pada tahun 1991. MD5 merupakan perbaikan dari MD4 setelah MD4 berhasil diserang oleh kriptanalis. MD5 ini menerima masukkan berupa pesan dengan ukuran sembarang dan menghasilkan message digest yang panjangnya 128 bit (Munir 2006).

Langkah-langkah

untuk

menghasilkan message digest adalah sebagai berikut:

1. Penambahan bit-bit pengganjal

Pesan mula-mula ditambahkan dengan bit-bit pengganjal sehingga panjang pesan (dalam satuan bit) kongruen dengan modulo 512. Setelah panjang data menjadi kelipatan 512, selanjutnya akan dikurangi 64 bit.

2. Penambahan nilai panjang pesan semula

Representasi sebesar 64 bit tersebut akan ditambahkan ke pesan.

3. Inisialisasi penyangga (buffer) MD.

MD5 membutuhkan 4 buah register sebagai buffer dengan panjang masing-masing 32 bit, sehingga total panjang buffer sebesar 128 bit. Keempat register ini diberi nama A, $\mathrm{B}, \mathrm{C}$ dan $\mathrm{D}$ yang diinisialisasi dalam nilai heksa sebagai berikut:

$$
\begin{aligned}
& \mathrm{A}=01234567 \\
& \mathrm{~B}=89 \mathrm{abcdef} \\
& \mathrm{C}=\text { fe dc ba } 98 \\
& \mathrm{D}=76543210
\end{aligned}
$$

4. Pengolahan pesan dalam blok berukuran 512 bit.

Dalam langkah ini, awalnya didefinisikan 4 buah fungsi dengan inputan 3 buah word 32 bit dan menghasilkan 1 buah word 32 bit.
Inisialisasi fungsi dinyatahkan dalam nama $F, G, H$ dan I adalah sebagai berikut:

$\mathrm{F}(\mathrm{X}, \mathrm{Y}, \mathrm{Z})=\mathrm{XY}$ or $(\sim \mathrm{X}) \mathrm{Z}$

$\mathrm{G}(\mathrm{X}, \mathrm{Y}, \mathrm{Z})=\mathrm{XZ}$ or $\mathrm{Y}(\sim \mathrm{Z})$

$\mathrm{H}(\mathrm{X}, \mathrm{Y}, \mathrm{Z})=\mathrm{X}$ xor $\mathrm{Y}$ xor $\mathrm{Z}$

$\mathrm{I}(\mathrm{X}, \mathrm{Y}, \mathrm{Z})=\mathrm{Y}$ xor $(\mathrm{X}$ or $(\sim \mathrm{Z}))$

Fungsi-fungsi tersebut masingmasing berisikan 16 kali operasi dasar terhadap inputan yang memanfaatkan suatu nilai elemen $\mathrm{T}$. nilai $\mathrm{T}$ adalah sebuah array berisi 64 elemen yang didapat dengan perhitungan tertentu menggunakan fungsi sinus. Pesan yang diinput dibagi menjadi $\mathrm{n}$ buah blok berukuran 512 bit. Setiap blok tersebut diproses bersama dengan buffer sehingga menghasilkan output sebesar 128 bit. Dalam proses ini terdiri dari 4 kali proses, masingmasing proses melakukan operasi tiap-tiap fungsi sebanyak 16 kali dan setiap operasi dasar memakai elemen T. Hasil akhir dari algoritma MD5 ini akan menghasilkan output (message digest) dengan panjang yang tetap sebesar 32 karakter.

\section{Algoritma RSA}

Rivest, Shamir dan Adleman atau disingkat RSA adalah sebuah public-key cipher yang dibuat oleh 3 orang peneliti dari MIT (Massachussets Institute of Technology) pada tahun 1978. Peneliti tersebut antara lain Ron Rivest, Adi Shamir dan Leonard Adleman. Cipher ini memiliki 2 kunci, yaitu kunci publik dan kunci rahasia. Keamanan cipher RSA ini terletak pada sulitnya menfaktorkan bilangan yang besar menjadi faktor-faktor prima (Coulouris 2005).

1. Perumusan Algoritma RSA

Algoritma kunci-publik RSA adalah algoritma kunci-publik yang paling populer (Munir 2006). Algoritma ini didasarkan pada 
teorema Euler yang menyatakan bahwa

$$
a^{\Phi(n)} \equiv 1(\bmod n)
$$

Dimana a relatif prima terhadap $\mathrm{n}$ dan $\Phi(\mathrm{n})=\mathrm{n}(1-1 / \mathrm{p} 1)(1-1 / \mathrm{p} 2) \ldots(1-$ $1 / \mathrm{pr})$ dimana $\mathrm{p} 1, \mathrm{p} 2, \ldots, \mathrm{pr}$ adalah faktor prima dari n. $\Phi(\mathrm{n})$ adalah fungsi yang menentukan berapa banyak dari bilangan-bilangan 1,2,3, $\ldots, \mathrm{n}$ yang relatif prima terhadap $n$.

Algoritma RSA secara sederhana dirumuskan sebagai berikut:

$$
\begin{aligned}
& E_{e}(m)=c=m^{e} \bmod n \\
& D_{d}(c)=m=c^{d} \bmod n
\end{aligned}
$$

Dimana :

1. $\mathbf{E}_{\mathbf{e}}(\mathbf{m})$ adalah fungsi enkripsi terhadap plainteks $\mathbf{m}$ dengan kunci-publik e.

2. Dd(c) adalah fungsi dekripsi terhadap chiperteks c dengan kunci-private $\mathbf{d}$.

Algoritma Membangkitkan Pasangan Kunci

1. Pilih dua buah bilangan prima sembarang, $\mathrm{p}$ dan $\mathrm{q}$.

2. Hitung $\mathrm{n}=\mathrm{p} \cdot \mathrm{q}$ ( sebaiknya $\mathrm{p} \neq \mathrm{q}$, sebab jika $\mathrm{p}=\mathrm{q}$ maka $\mathrm{n}=\mathrm{p}^{2}$ sehingga $\mathrm{p}$ dapat diperoleh dengan menarik akar pangkat dua dari $n$ ).

3. Hitung $\Phi(\mathrm{n})=(\mathrm{p}-1)(\mathrm{q}-1)$.

4. Pilih kunci publik, e, yang relatif prima terhadap $\Phi(\mathrm{n})$.

5. Bangkitkan kunci privat dengan menggunakan persamaan

$$
\mathrm{e}^{*} \mathrm{~d} \equiv 1(\bmod \Phi(\mathrm{n})) \text {. }
$$

(Perhatikan bahwa ${ }^{*} \mathrm{~d} \equiv 1(\bmod$ $\Phi(\mathrm{n}))$ ekivalen dengan

$$
\mathrm{e}^{*} \mathrm{~d}=1+\mathrm{k} \Phi(\mathrm{n})
$$

sehingga secara sederhana $d$ dapat dihitung dengan

$$
\mathrm{d}=\frac{1+\mathrm{k} \Phi(\mathrm{n})}{e}
$$

Hasil dari algoritma di atas:

Kunci publik (e, n) dan kunci privat $(\mathrm{d}, \mathrm{n})$

Catatan: $n$ tidak bersifat rahasia, sebab ia diperlukan pada perhitungan enkripsi/dekripsi.

\section{Algoritma Enkripsi/Dekripsi}

\section{Enkripsi}

a. Ambil kunci publik penerima pesan, e, dan modulus $\mathrm{n}$.

b. Nyatahkan plainteks $\mathrm{m}$ menjadi blok-blok $\mathrm{m}_{1}, \mathrm{~m}_{2}, \ldots$, sedemikian sehingga setiap blok merepresentasikan nilai di dalam selang $[0, \mathrm{n}-1]$.

c. setiap blok $m_{i}$ dienkripsi menjadi blok $c_{i}$ dengan rumus $c_{i}=m_{i}{ }^{e} \bmod$ n.

\section{Dekripsi}

Setiap blok cipherteks $c_{i}$ didekripsi kembali menjadi blok $m_{i}$ dengan rumus $m_{i}=c_{i}{ }^{d} \bmod n$.

\section{METODE}

Software Development Process adalah kerangka dasar yang digunakan dalam proses pembuatan software. Software development process memiliki beberapa model, diantaranya waterfall model, iterative model, dan spiral model. Setiap model memiliki pendekatannya masingmasing dalam menyelesaikan masalah yang ditemukan dalam proses pembuatan software (Jacobson et al. 1999)

Dengan rancangan penelitian untuk penyelesaian software, penulis mengikuti tahapan dalam metodologi Waterfall Model of Software Development Process. Langkah-langkahnya adalah requirements, design, implementation, verification, dan maintenance. 


\section{HASIL DAN PEMBAHASAN}

Fungsi dan batasan yang dimiliki oleh aplikasi yang dibangun adalah sebagai berikut:

1. Fungsi Aplikasi

a. Menjamin kerahasiaan pesan.

b. Menjamin integritas pesan.

c. Mengetahui pesan yang diterima itu telah dimodifikasi atau tidak.

d. Mengatasi masalah nirpenyangkalan.

2. Batasan Aplikasi

a. Pesan (plainteks) yang akan ditandatangani dalam bentuk file *.txt.

b. Algoritma kunci-publik yang digunakan dalam aplikasi ini adalah RSA dengan panjang kunci 256 bit.

c. Fungsi hash yang digunakan adalah fungsi hash MD5 128 bit.

d. Aplikasi bersifat Peer To Peer.

e. Bahasa pemrograman yang digunakan dalam pembuatan aplikasi ini adalah Delphi 7.

\section{Design}

Gambar 2 menunjukkan bagaimana cara untuk menghubungkan 2 komputer, yaitu dengan mengatur alamat IP dan port masing-masing komputer. Jika terhubung maka kunci dapat di-generate. Setelah itu, 2 komputer akan saling menukar kunci publik yang akan berfungsi dalam proses enkrip/dekrip pesan.

Flowchart kirim ditunjukkan pada Gambar 3. Pesan dimasukkan dan dihitung nilai hash-nya. Nilai hash yang dihasilkan akan dienkrip menggunakan kunci privat pengirim kemudian pesan beserta hasil enkrip dari nilai hash, dienkrip dengan menggunakan kunci publik penerima. Selanjutnya pengirim mengirimkan hasil enkripsi tersebut ke penerima.

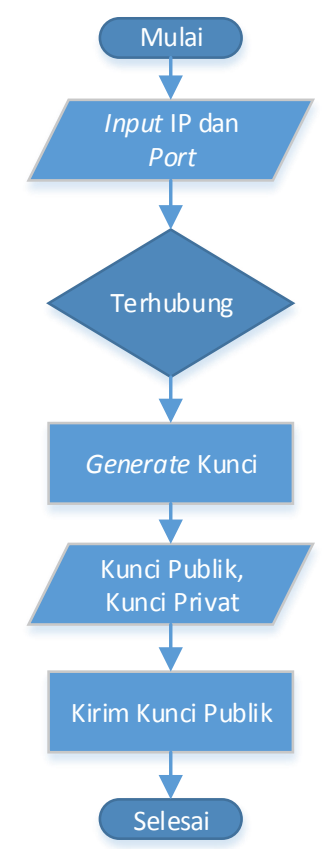

Gambar 2. Flowchart pengaturan koneksi dan generate kunci

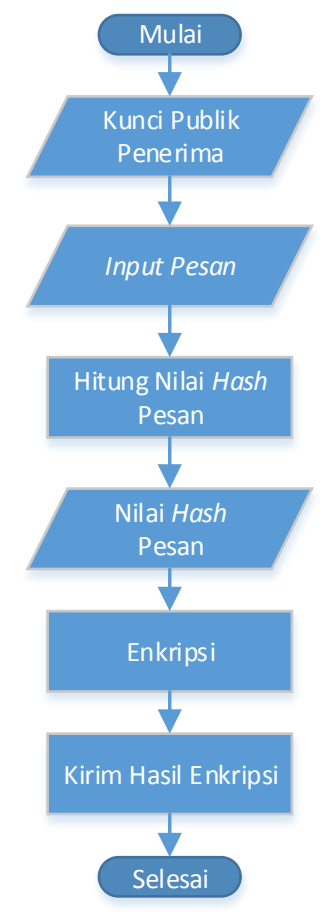

Gambar 3. Flowchart kirim 


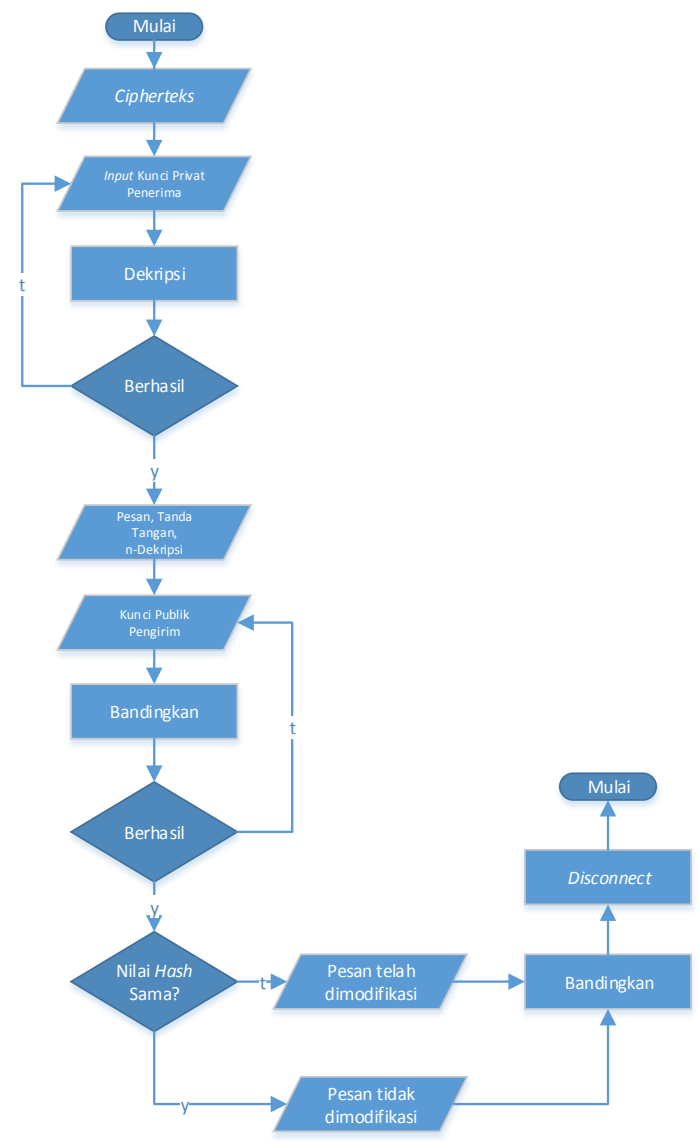

Gambar 4. Flowchart terima

Hasil enkripsi yang diterima didekripsi dengan menggunakan kunci privat dari penerima sebagaimana ditunjukkan pada Gambar 4. Hasil dekripsinya adalah pesan dan hasil enkripsi nilai hash oleh pengirim. Jika berhasil didekripsi, akan terlihat juga banyaknya percobaan dekripsi. Ini dimaksudkan agar penerima mengetahui jika ada orang yang bukan penerima yang mencoba mendekripsi cipherteks dari pengirim. Selanjutnya masuk pada proses Bandingkan, dengan menggunakan kunci publik pengirim, hasil enkrip dari nilai hash pengirim didekripsi kemudian nilai hash dari pesan yang diterima tersebut dihitung, lalu hasil dekrip dan nilai hash yang dihitung dari pesan yang diterima kemudian dibandingkan. Jika sama berarti pesan tidak dimodifikasi sebaliknya jika berbeda maka pesan tersebut sudah dimodifikasi.
Flowchart proses MD5 pada sistem dapat dilihat pada Gambar 5. Masukkan pesan yang akan dihitung nilai hash-nya. Kemudian pesan tersebut ditambahkan bitbit pengganjal terlebih dahulu. Pesan mulamula ditambahkan dengan bit-bit pengganjal sehingga panjang pesan (dalam satuan bit) kongruen dengan modulo 512. Selanjutnya pesan ditambahkan dengan nilai panjang semula. Representasi sebesar 64 bit ditambahkan ke pesan. Selanjutnya inisialisasi penyangga MD sebanyak 4 buah register dengan panjang masing-masing 32 bit, sehingga total panjang buffer sebesar 128 bit. Setelah itu, pesan diolah dalam blok berukuran 512 bit. Dalam proses ini, terdapat operasi dasar dan nilai dari elemen T. Nilai $T$ adalah sebuah array berisi 64 elemen yang didapat dengan perhitungan tertentu menggunakan fungsi sinus. Prosesnya terdiri dari 4 kali proses, masingmasing proses melakukan operasi tiap-tiap fungsi sebanyak 16 kali dan setiap operasi dasar memakai elemen T. Hasil akhirnya adalah nilai hash sepanjang 32 karakter.

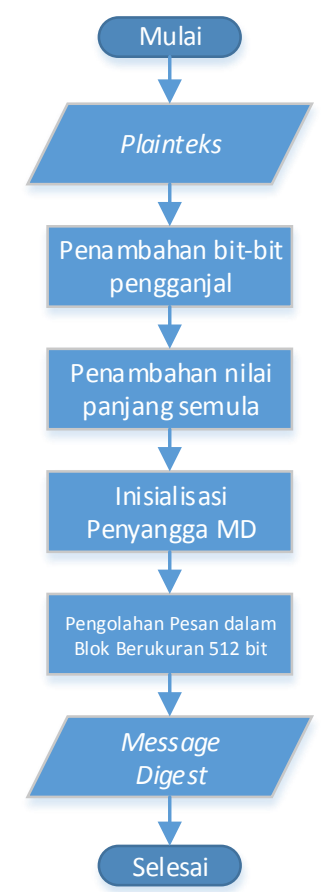

Gambar 5. Flowchart proses MD5 pada Sistem 


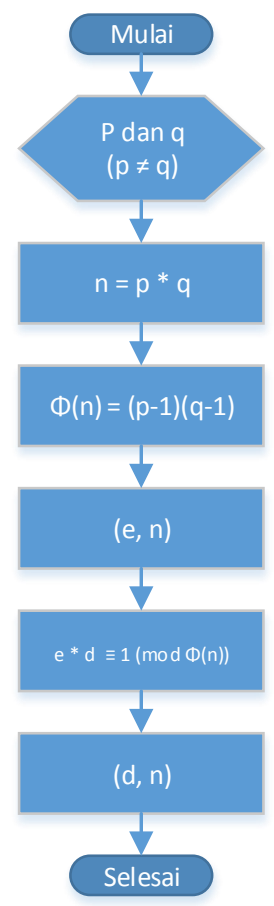

Gambar 5. Flowchart proses pembangkitan kunci

Untuk membangkitkan kunci publik dan kunci privat, tentukan terlebih dahulu dua buah bilangan prima secara acak (sembarang), p dan q. Kemudian hitung modulus (n) dengan cara mengalikan kedua bilangan tersebut $(n=p . q)$. Setelah itu, hitung faktor prima dari $\mathrm{n}(\Phi(\mathrm{n}))$ dengan rumus $\Phi(\mathrm{n})=(\mathrm{p}-1)(\mathrm{q}-1)$. Tentukan kunci publik dari faktor prima yang didapat. Untuk mencari kunci privat, digunakan persamaan $(\mathrm{e} * \mathrm{~d} \equiv 1(\bmod \Phi(\mathrm{n})))$, persamaan ini equivalen dengan $(\mathrm{e} * \mathrm{~d}=1+$ $\mathrm{k} \Phi(\mathrm{n}))$ sehingga secara sederhana d dapat dihitung dengan $\mathrm{d}=\frac{1+\mathrm{k} \Phi(\mathrm{n})}{e}$. Hasilnya adalah kunci privat.

\section{Keterangan}

$\mathrm{p}$ dan $\mathrm{q} \quad$ : bilangan prima

$\mathrm{n} \quad$ : modulus

$\Phi(\mathrm{n}) \quad$ : fungsi untuk menentukan berapa banyak dari bilanganbilangan $1,2,3, \ldots, \mathrm{n}$ yang relatif prima terhadap $n$.

e : kunci publik

d : kunci privat

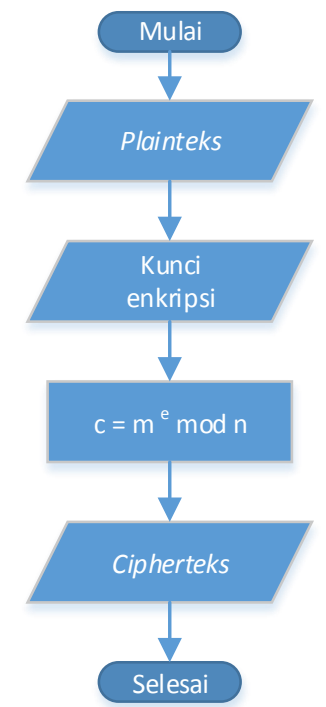

Gambar 6. Flowchart proses enkripsi pesan

Untuk mengenkripsi pesan (plainteks), masukkan kunci publik. Proses enkripsi digambarkan dengan rumus $(\mathrm{c}=\mathrm{m}$ $\left.{ }^{\mathrm{e}} \bmod \mathrm{n}\right)$, dimana c (cipherteks), m (pesan), e (kunci publik) dan n (modulus). Dengan rumus tersebut pesan dibagi menjadi blokblok $\mathrm{m} 1, \mathrm{~m} 2, \ldots, \mathrm{m}_{\mathrm{i}}$ sehingga setiap blok merepresentasikan nilai di dalam selang [0, $n-1]$. Setiap blok $m_{i}$ dienkripsi menjadi blok $c_{i}$ dengan rumus $\left(c_{i}=m_{i}{ }^{e} \bmod n\right)$. Hasilnya berupa pesan yang telah dienkripsi (cipherteks).

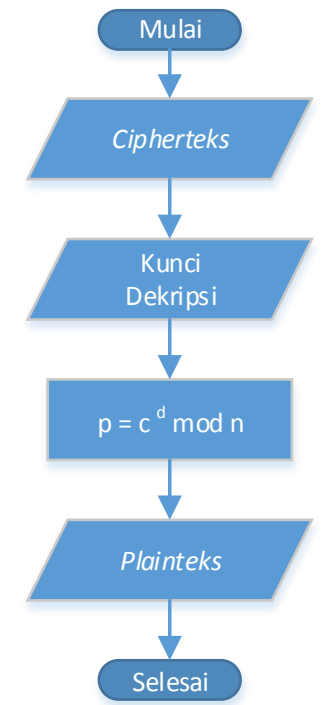

Gambar 7. Flowchart proses dekripsi 
Untuk mendekripsi pesan (cipherteks), masukkan kunci privat. Setiap blok cipherteks $\mathrm{c}_{\mathrm{i}}$ didekripsi menjadi blok $m_{i}$ dengan rumus $\left(m_{i}=c_{i}{ }^{d} \bmod n\right)$. Hasilnya adalah pesan semula.

\section{Implementasi}

Implementasi sisstem ini dilakukan pada media Notebook AXIOO ZETTATEC0252W menggunakan Sistem Operasi Windows XP SP2 dan alamat IP localhost.

Gambar 8 menunjukkan Form koneksi dan generate kunci. Form kirim dapat dilihat pada Gambar 9. Form terima dapat dilihat pada Gambar 10.

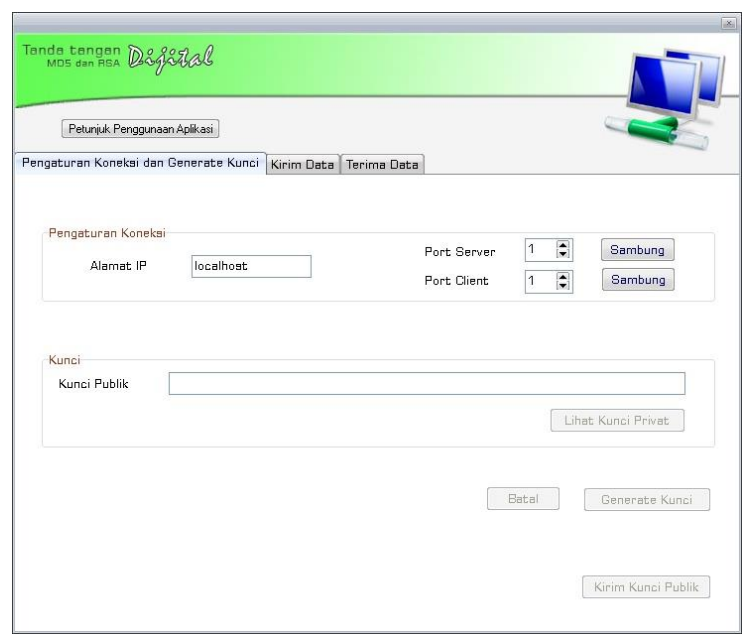

Gambar 8. Form koneksi dan generate kunci

Kode program yang digunakan untuk generate kunci adalah sebagai berikut:

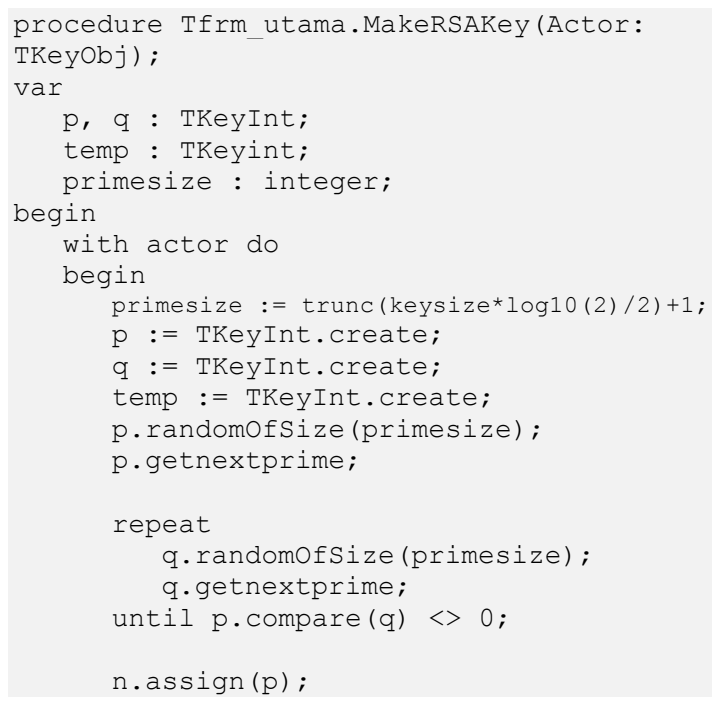

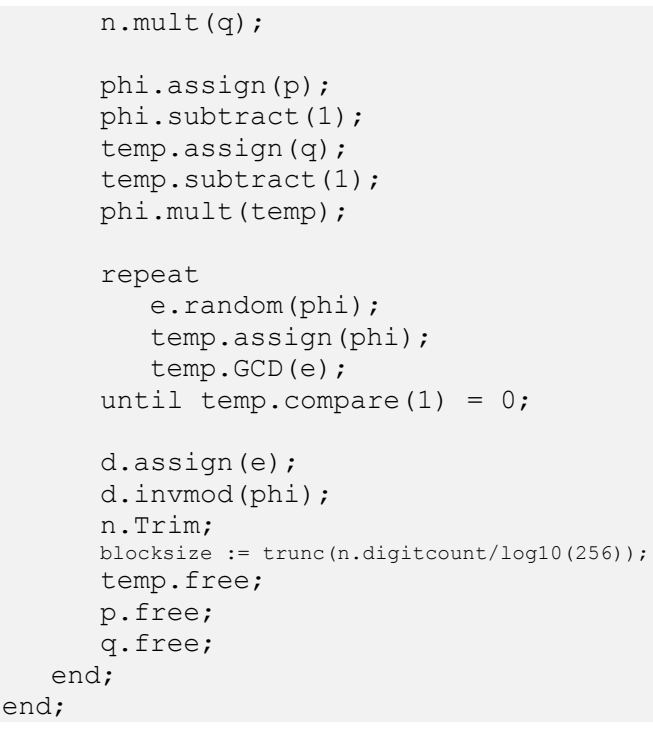

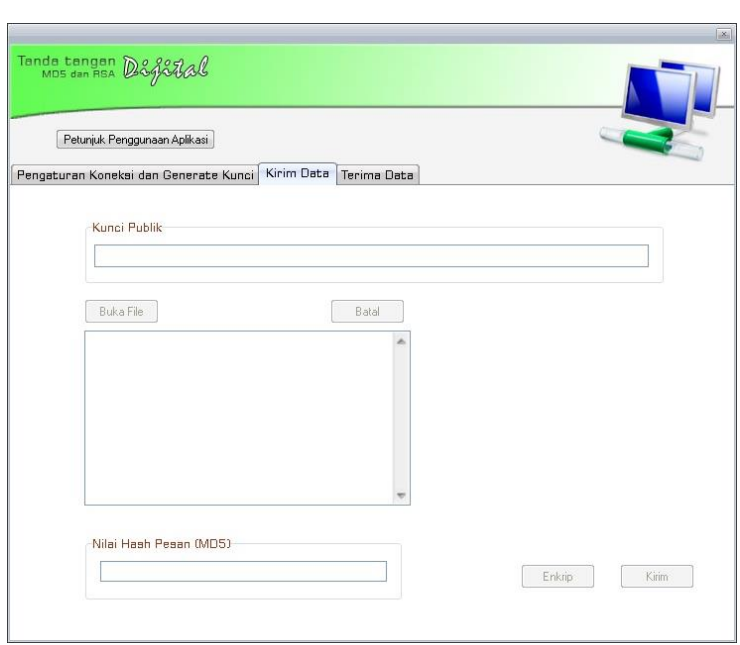

Gambar 9. Form kirim

Kode program (fungsi) yang digunakan untuk menentukan nilai hash pesan adalah sebagai berikut:

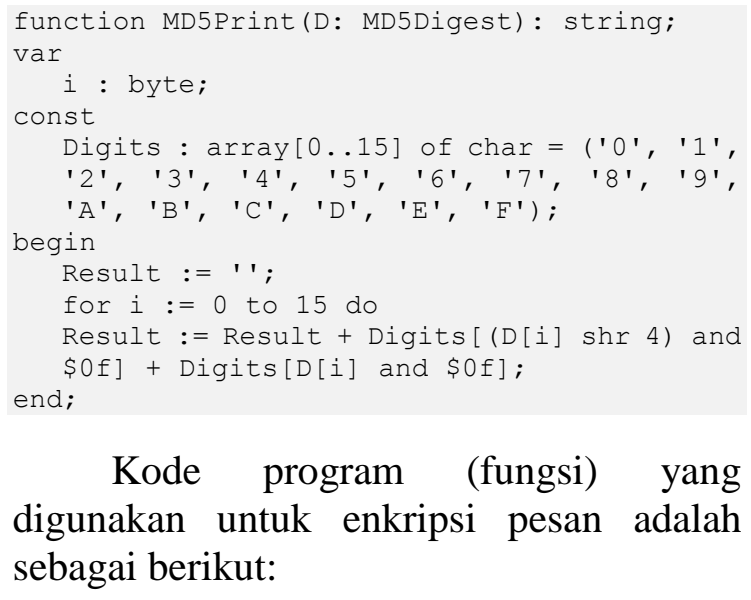

Kode program (fungsi) yang digunakan untuk enkripsi pesan adalah sebagai berikut: 

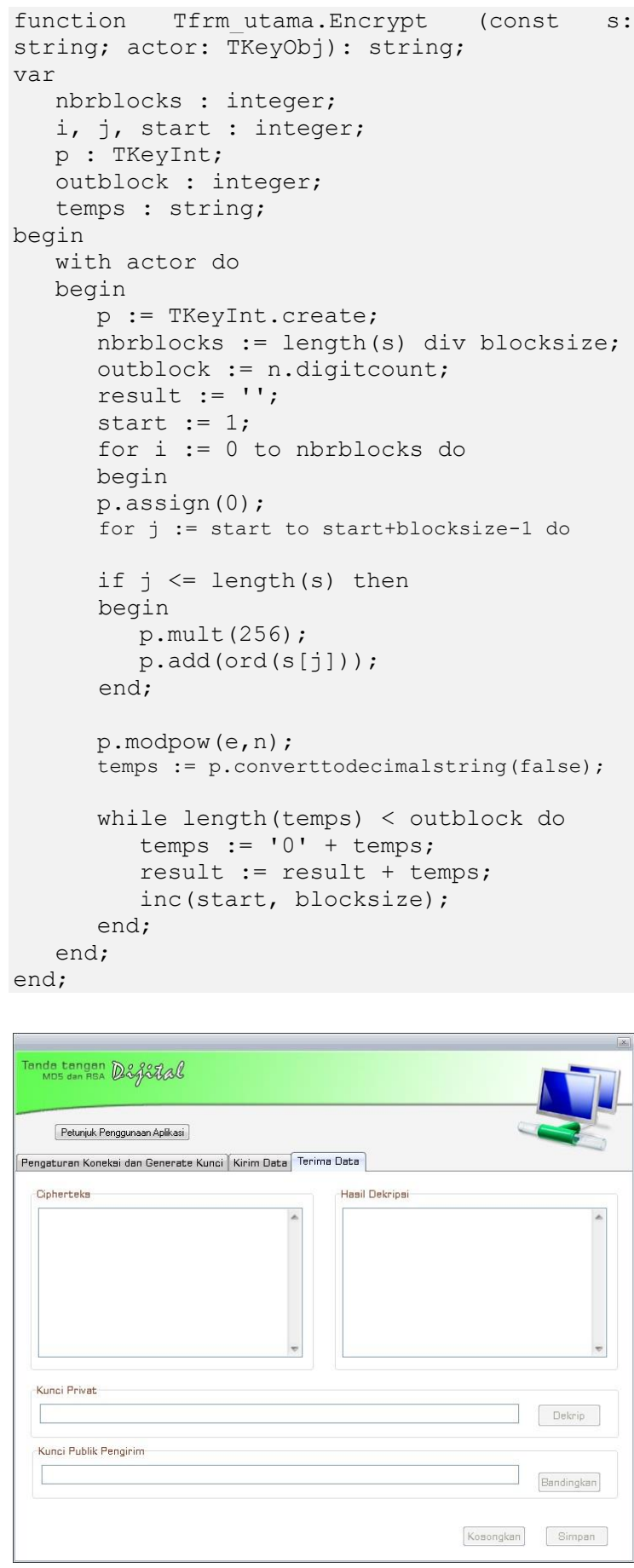

Gambar 10. Form terima

Kode program (fungsi) yang digunakan untuk dekripsi pesan adalah sebagai berikut:

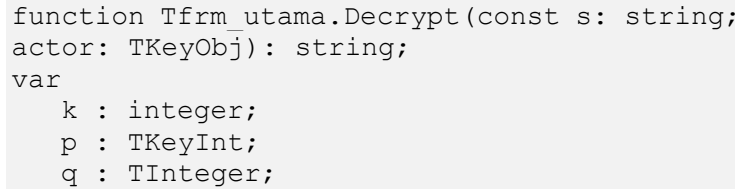

function Tfrm_utama.Decrypt(const s: string;

q : TInteger;

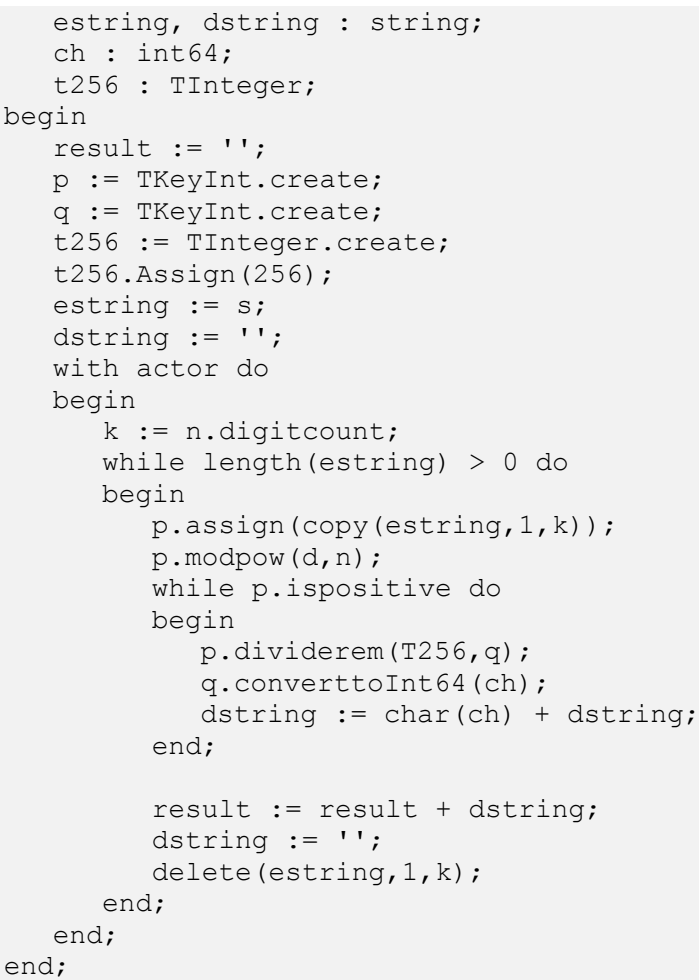

\section{E. KESIMPULAN}

Tanda tangan dijital dengan fungsi hash MD5 dan enkripsi/dekripsi menggunakan algoritma RSA 256 bit telah berhasil dirancang dan diimplementasikan ke dalam sebuah aplikasi untuk pertukaran informasi yang berupa pesan. Adapun saran yang sekiranya dapat bermanfaat untuk pengembangan sistem selanjutnya adalah sebagai berikut:

1. Untuk mencegah serangan man-inthe-middle attack terhadap aplikasi ini, kunci publik masing-masing diumumkan terlebih dahulu agar pengirim dan penerima saling mengetahui kunci publik masingmasing.

2. Security lebih ditingkatkan lagi, salah satunya dengan membangkitkan kunci RSA lebih besar dari 256 bit.

3. Aplikasi ini dapat dikembangkan di jaringan yang lebih luas/besar. 


\section{F. DAFTAR PUSTAKA}

Coulouris, G.J., Dollomore., Kindberg, T. 2005. Distributed Systems Concepts and Design: fourth edition. Addison Wesley.

Jacobson, I., Booch, G., Rumbaugh, J. 1999. The Unified Software Development Process (Object Technology Series). Addison Wesley.

Juliasari, N. 2002. Penerapan Teknik Enkripsi Blok dan RC4 Stream Cipher pada Database Nasabah Koperasi. Budi Luhur.

Krutz, R.L., Vines, R.D. 2003. The CISSP Prep Guide Gold Edition. Wiley.

Menezes, A.J., van Oorschot, P.C., Vanstone, S.A. 1996. Handbook of Applied Cryptography. CRC Press.

Munir, R. 2006. Kriptografi. Bandung: INFORMATIKA.

Schneiner, B. 1996. Applied Cryptography $2^{\text {nd }}$. John Wiley \& Sons.

Wibowo, A.M. 1998. Mengenal Tanda Tangan dan Sertifikat Digital. Infokomputer Online.

Youd, D. 1996. An Introduction to Digital Signatures. 